https://doi.org/10.48009/1_iis_2005_365-371

\title{
INFORMATION SYSTEMS OR INFORMATION TECHNOLOGY? A CASE STUDY IN CURRICULAR FOCUS
}

\author{
Dr. Floyd A. Wilkes, Utah Valley State College, wilkesfl@uvsc.edu \\ Dr. Christopher G. Jones, Utah Valley State College, jonescg@uvsc.edu
}

\begin{abstract}
In 2004, three universities piloted ABET general computing criteria guidelines for undergraduate degree programs in Information Technology (IT). Just three years earlier, in December 2001, ABET had approved criteria for accreditation of Information Systems (IS). For institutions with information-related programs that span IT, IS, and Information Management (IM), this has posed a challenge: Given limited resources, a political climate opposed to degree proliferation, and administrative mandates to secure specialized accreditation, which program guidelines should be adopted? This paper chronicles the curricular pains of a large public comprehensive four-year college as it struggles with the question of whether to "go IT or IS. ” A variety of scenarios are examined that lead to a departmental vote on strategic direction. Lessons learned from the process are enumerated.
\end{abstract}

Keywords: information systems accreditation, information technology accreditation, ABET, $\mathrm{CAC}$, information systems education, information technology education

\section{INTRODUCTION}

Fall 2003, just two short years after adopting formal criteria for specialized accreditation of undergraduate Information Systems programs, the Accreditation Board for Engineering and Technology (ABET) Board of Directors approved general criteria for sister discipline, Information Technology [4]. By December 2004, three universities had piloted the general criteria for accrediting computing programs in Information Technology and had hosted Computing Accreditation Commission (CAC)/ABET accreditation visits under the general computing criteria guidelines. Draft program standards for Information Technology [6], as well as a draft Body of Knowledge [7], have been developed by Special Interest Group for Information Technology Education (SIGITE) Curriculum Writing Committee.

The formalization of Information Technology as a separate academic discipline provides yet another curricular alternative for students seeking careers in information-related fields. The SIGITE Curriculum Writing Committee defines Information Technology as follows:

Information Technology (IT) in its broadest sense encompasses all aspects of computing technology. IT, as an academic discipline, focuses on meeting the needs of users within an organizational and societal context through the selection, creation, application, integration and administration of computing technologies.

This is a rather broad definition and could be construed to include Information Systems were it not for the fact that an ABET IS program requires a minimum of 15 credit hours in an Information Systems Environment [2]. Nevertheless, just as it is possible to fashion an 
information systems program to satisfy accreditation guidelines for both ABET and AACSB, it would seem feasible to design an information technology program for dual accreditation as both IT and IS. For information-related programs that span both IT, IS, and Information Management (IM), this has posed a challenge: Given limited resources, a political climate opposed to degree proliferation, and administrative mandates to secure specialized accreditation, which program guidelines should be adopted? Would it be better to design stand-alone programs in Information Systems, Information Technology, and Information Management? Or would be better to straddle multiple accreditation guidelines to design a single program that meets all three outcomes objectives by using a combination of a common core and specialized emphases? And if a single program is the best approach, should it be IS-centric, IT-centric, or IM-centric? With only a handful of institutions currently ABET accredited for IS and none officially accredited for IT, the question of specialized accreditation now becomes a question of which specialization Information Technology or Information Systems. (ABET does not accredit information management/office technology programs). Through an actual case study, this paper explores the challenges facing an institution with a history in IS, IT, and IM as it attempts to align its curriculum for future accreditation.

\section{BACKGROUND}

Utah Valley State College (UVSC) is a public comprehensive U.S.A-based four-year institution primarily serving students living in and around Utah County in the state of Utah. The college has a student population of approximately 24,000 coming from all 50 states and nearly 80 countries. UVSC traces its roots to 1941 when it began as a technical school. By 1987 the school had transformed itself into a community college and the name was changed to Utah Valley Community College. In 1993 the college began offering four-year degrees which was reflected in the name being changed to Utah Valley State College.

In the year 2000, the Computer Science and Information Systems (CSIS) department in the School of Business had been offering two-year and four-year degrees for seven years. However, a new School of Computer Sciences and Engineering (CS\&E) had been created, so the CSIS department was divided and the "Computer Science" part was moved into this school.

The "Information Systems" portion remained in the School of Business and was combined with an existing Business Systems Administration (BSA) department which focused their curriculum on office occupations and computer applications suites (word processors, spreadsheets, etc.). The combined department was renamed Business Computer Information Systems (BCIS). A BS degree in Information Technology (BS IT) with emphases in Information Technology (IT) and Administrative Information Management (AIM) was offered plus some related two-year degrees.

At the time CSIS was divided, the curriculum of the IT emphasis included only six business classes, however, it quickly evolved into an Information Systems-centric program based on the IS 2002 model curriculum [3] and the ABET Information Systems accreditation criteria [2]. It was the view of the faculty that no more than one or two classes needed to be changed for the program to be fully compliant with the ABET IS guidelines. Other than the fact that the two parts of the BCIS department offered the same BS IT degree, the two merged faculty groups operated 
essentially as independent entities with only three or four courses that constituted a common core between the AIM and IS emphases.

After operating together for a year, a new dean in the School of Business separated the departments for administrative purposes with the IT/IS part retaining the BCIS name and the AIM part renamed as Business Systems Administration and Education (BSAE). However, due to a moratorium on new degree programs imposed by the State Board of Regents, it was not possible to offer a separate BS degree in each department, so both departments continued to offer the BS IT degree with different emphases. The result was a very confusing situation in which two departments, one (BCIS), offering an Information Systems program that was called Information Technology, and another (BSAE), offering an Administrative Information Management program, and where both programs culminated in the same BS IT degree.

\section{RECENT DEVELOPMENTS}

For the next two years in the School of Business, the BCIS and BSAE departments operated under this arrangement. There were, however, other forces working which would eventually bring new changes. First, there was a desire on the part of the School of Business to obtain AACSB accreditation. Next were pressures from within the institution to consolidate all computer related programs on campus into one school by moving them into CS\&E. And finally, there were questions related to the emerging discipline of Information Technology and whether UVSC should have an IT program and if so, how it should be positioned relative to existing programs.

AACSB accreditation [1] presented some problems for the IS program because according to the guidelines under which the school was seeking accreditation, no program could have more than $50 \%$ of its classes taught within the School of Business. The BS IT degree in BCIS had approximately $60 \%$ of the program being taught in the School of Business.

With regard to the issue of consolidating computer programs in one school, a task force with representatives from the administration, the two schools and the BCIS department was appointed to study the proposal. The final decision from the administration, based on a task force recommendation, was that the BCIS department with the BS IT degree including both the IS and the AIM emphases be moved to CS\&E as a single department which was named Computer Information Technology and Education (CITE). As a part of this departmental and school reorganization, eleven networking courses along with the two faculty members who teach the courses were moved from Computer and Networking Sciences department into the new CITE department. This move was completed for Fall Semester 2004.

\section{CURRENT CHALLENGES}

The first challenge faced by the new department has been to figure out what CITE really is. It has remnants of strong IS and AIM programs. It has elements of a network administration and IT infrastructure program. The department faculty and school administration desire to have the department programs nationally accredited. In addition, students are not quite sure what the department is and faculty have a hard time explaining things to them because they (the faculty) 
are not quite sure either. Finally, there is a need to decide on a curriculum so that the looming deadline for publishing curriculum can be met and students can be informed about department offerings.

It was decided that final decisions on curriculum could not be made until the department had a better idea about what it wanted to be. Accordingly, a document was prepared that described three possible scenarios. Two of the scenarios had two options within them so there was a total of five different options. The scenarios presented address issues related to the BS IT degree and the AIM, networking (NW), and information systems (IS) programs. The following assumptions regarding current conditions and direction were adopted to guide the decision making:

1. Accreditation enhances the legitimacy and recognition of programs, and provides additional leverage when vying for resources within the institution. Therefore, the CITE faculty and the administration desire accreditation for CITE programs.

2. That the necessary administrative support at the school and college levels can be obtained for the proposed organizational and degree restructuring.

3. That student enrollment in CITE programs, which at the present time is only marginally adequate to support department programs, will increase but the increase will be slower and take longer than the increases experienced in the past such as during the time of the .com boom.

4. That resources will continue to be scarce and that CITE will likely not receive significant additional resources for new faculty or other needs in the near future, probably until enrollments increase significantly.

Assumptions three and four portend a need to operate as efficiently as possible in order to provide faculty with reasonable workloads and number of preps.

The three scenarios were circulated to the CITE faculty and the faculty was asked to rank each of the options. The three scenarios are described below:

Scenario \#1 - The Information Systems Approach. The department would continue what it has been doing with these differences:

1. Divide the BS IT degree and rename the IT part to BS in Information Systems. Rename what was called the IT emphasis to something like Enterprise Computing or Enterprise Systems emphasis.

2. Move the AIM program to a separate degree called BS in Administrative Information Management. This degree could be housed either in CITE or moved to another department. Either way it could be managed as a separate entity.

3. Add a new emphasis to athe BS in Information Systems degree called Network Administration that would provide the new network offerings of the department. 
Scenario \#2 - Become an IT department with an IT degree. Keep the BS IT degree name and make these changes:

1. Implement an IT curriculum following the IT program guidelines in the CC2004 document [5] and comply with the proposed IT accreditation criteria [2].

2. Provide an IS program as an emphasis in the IT degree and make it compliant with the IT accreditation guidelines.

3. Move the AIM program to a separate degree called BS in Administrative Information Management. This degree could be housed either in CITE or moved to another department. Either way it could be managed as a separate entity.

\section{Scenario \#3 - Integrate the AIM, IS and network programs into a single IT curriculum.}

1. All students in the department would progress through a single integrated model of the curriculum beginning with a common core based on the ABET IT body of knowledge and leading to three paths or emphases with specialization classes defined for the AIM, NW or IS emphasis.

2. This model should result in a reduced number of classes for the same number of students. With this condition, multiple sections of the same course become possible, leading to a reduction in preps.

Both Scenario \#1 and Scenario \#2 have the effect of spreading department resources over a larger number of classes because of having two degrees. Managing department resources becomes more difficult because sections are smaller and the number of preparations is greater. Scenario \#3 provides a single model of the curriculum with a common core for all students. The result of this approach should be a smaller number of larger sections that the department would need to provide.

Faculty were asked to rank on a scale of 1 (first choice) to 5 (last choice) the five options derived from the three scenarios described above:

\section{Option Name Description}

ISC

ISS

ITC

ITS

ITT
Scenario \#1 - an IS degree for NW and IS with a separate AIM degree, all in CITE.

Scenario \#1 - an IS degree for NW and IS in CITE with a separate AIM degree housed in its own or another department.

Scenario \#2 - an IT degree for NW and IS with a separate AIM degree, all in CITE.

Scenario \#2 - an IT degree for NW and IS in CITE with a separate AIM degree housed in its own or another department.

Scenario \#3 - an IT degree with a common core curriculum and separate emphases for AIM, NW and IS all in CITE. 
A vote of the CITE faculty was taken on February 18, 2005. The final tally resulted in the following outcome: (The lower the number the higher the ranking)

$\begin{array}{llllll}\text { Option: } & \underline{\text { ITC }} & \underline{\text { ITS }} & \underline{\text { ITT }} & \underline{\text { ISC }} & \underline{\text { ISS }} \\ \text { Rank: } & 1 & 2 & 3 & 4 & 5 \\ \text { Tally: } & 20 & 34 & 35 & 38 & 53\end{array}$

As the vote indicates, the mandate was for two four-year degrees -- one for Administrative Information Management and another for Information Technology with emphases in Networking and Information Systems. Both degrees should be housed in CITE.

\section{LESSONS LEARNED}

One of the key lessons learned from the exploration of various curricular scenarios, was that straddling the common ground between IS and IT is, in fact, doable. There is considerable overlap between the IS body of knowledge [3] and the IT body of knowledge [7]. Students interested in IT are often the same students interested in IS. Where divergence takes place is in the advanced coursework, easily accommodated through IS-specific or IT-specific emphases.

When a third perspective, such as information management, was added to the mix, finding a foundational core that straddled three disciplines became difficult. Target student populations for Administrative Information Management are often returning students, displaced homemakers, and students seeking careers that focus on office technologies rather than enterprise-level transaction-based systems. IM students use office applications to manage departmental processes. Discrete math, business calculus and proficiency in modern programming languages, while appropriate for IT and IS, provide more technical foundation than desired at the expense of needed business coursework. For a common core to be viable, there must be a fairly uniform student population and with similar goals for system scale.

Offering an IS program under an IT degree title lends itself to "brand confusion". Even though the current B.S. Information Technology - Information Technology emphasis conforms to the ABET Information Systems program criteria [2] and the IS 2002 Model Curriculum [3], several students entering the program have been very explicit that they are not interested in doing system development. When pressed as to their specific career goals, students respond they are interested in installing, managing or troubleshooting the technology or developing web pages. Perhaps this is a reflection of the type of work experience students have, as the majority of the students work part time in the industry while attending college. Increasingly, students completing an undergraduate degree in information systems are securing full time employment as "funky techs" -- functional technicians. An IT-centric curriculum, as opposed to an IS-centric curriculum, provides a "generalist" skill set that is more amenable to becoming a funky tech.

\section{CONCLUSION}

Curriculum examination is a reflective process often accompanied by heated discussion. Aligning curricular objectives requires a change in world view. Faculty steeped in a particular approach to information are understandingly reluctant to cede to a particular centricity. 
Information Systems faculty accustomed to an IS-centric curriculum find it painful to adopt an IT-centric view. Information Management faculty intimate with a departmental-level scope for technology applications may be uncomfortable with the expansiveness of enterprise-level systems prevalent in IS or IT. In a perfect world, all technological perspectives would be equally appropriate and equally valued. When faced with limited resources, being all things to all people is rarely an option. Selecting the right information focus depends on available accreditation guidelines, regional employment needs, student populations, and faculty expertise. For the institution under study, it appears the faculty consensus is that an IT-centric four-year curriculum with emphases in network infrastructure and enterprise systems development coupled with a separate four-year administrative information management degree bests balances these considerations. Whether members of the CITE Industry Advisory Committee concur remains to be seen.

\section{REFERENCES}

1. AACSB International. (February 14, 2001). Standards for Business Accreditation. Retrieved February 28, 2005 from http://www.aacsb.edu/accreditation/standards.asp

2. ABET Computing Accreditation Commission. (November 1, 2004). Criteria for Accrediting Computing Programs: Effective for Evaluations During the 2005-2006 Accreditation Cycle. Retrieved February 25, 2005 from http://www.abet.org/images/Criteria/C001\%200506\%20CAC\%20Criteria\%2011-29-04.pdf

3. Gorgone, J.T., Davis, G.B., Valacich, J.S., Topi, H., Feinstein, D.L., \& Longenecker, H.E. Jr. (2002). IS 2002: Model curriculum and guidelines for undergraduate degree programs in Information Systems, Association for Information Systems, Atlanta, GA.

4. Kohun, F. G. \& Wood, D. F. (2003). The ABET CAC accreditation experience-Intent and reality-The Information Systems perspective. Information Systems Education Journal, 1(43). Retrieved February 22, 2004, from http://isedj.org/1/43/

5. Joint Task Force for Computing Curricula 2004. (November 22, 2004). Computing Curricula 2004: Overview Report Including a Guide to Undergraduate Degree Programs in Computing for Undergraduate Degree Programs in Computer Engineering, Computer Science, Information Systems, Information Technology, and Software Engineering. Retrieved February 28, 2005 from http://www.acm.org/education/Overview_Draft_11-22-04.pdf

6. SIGITE Curriculum Writing Committee. (2004). Program Standards for Information Technology (Draft). Retrieved February 28, 2005 from http://www.sigite.org/activities/accreditation/downloads/CAC\%20IT\%20Standards\%20V2\% 201.pdf

7. SIGITE Curriculum Writing Committee. (September 21, 2004). The Information Technology Body of Knowledge (Draft). Retrieved February 28, 2005 http://sigite.acm.org/activities/curriculum/downloads/IT\%20Body\%20of\%20Knowledgedraf\%201.pdf?sigite $=7$ f03fb23bbbc78ce0ef0d2dea24ac $1 \mathrm{~d} 7$ 